\title{
Interlinkage Between Real Exchange Rate And Current Account Behaviors: Evidence From India
}

\author{
Mohamed Arouri, CRCGM-Université d'Auvergne \& EDHEC Business School, France \\ Arif Billah Dar, Pondicherry University, Puducherry, India \\ Niyati Bhanja, Pondicherry University, Puducherry, India \\ Aviral Kumar Tiwari, ICFAI University Tripura, Tripura, India \\ Frédéric Teulon, IPAG Business School, IPAG - Lab, France
}

\begin{abstract}
The study analyzes the dynamic interlinkage between India's real effective exchange rate and real current account deficit using standard VAR and structural VAR (SVAR). The empirical analysis suggests that a real currency appreciation leads to an improvement in the current account deficit, thereby highlighting the occurrence of permanent shocks such as technical innovations, productivity shocks, and changes in tastes and preferences. A positive shock to the current account deficit leads to an appreciation in the real exchange rate. Moreover, both current account and real exchange rates are found to be affected by the changes in these variables themselves rather than changes in the other variables in the system.
\end{abstract}

Keywords: Real Exchange Rate; Current Account; India; VAR; SVAR

\section{INTRODUCTION}

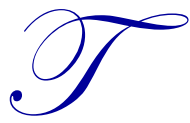

he interaction between the exchange rate and current account remains critical to the formulation of an appropriate exchange rate policy and in devising the correct policy response to economic instability. However, real exchange rates and current account balance typically exhibit seemingly inexplicable behavior. Modeling the behavior of real exchange rates and current account balance is one of the most challenging and enduring research areas in the literature of open economy macroeconomics. Until recently, despite their dynamic interactive characteristics, research efforts have focused on the nature of real exchange rates and current account separately (Lee and Chinn; 2006). In this context, Kim et al. (2012) contended that an understanding of the combined dynamics of the real exchange rate and current account is important not only for policy modeling, but also for understanding the mechanism of 'global rebalancing.' This study extends the existing literature by assessing the behavior of both of these variables within a consolidated holistic framework.

Following Kim et al. (2012), the literature on exchange rates and current account can be broadly categorized into two strands. The first strand of studies conduct causality analysis between the two variables (Devereux and Genberg, 2007; Leonard and Stockman, 2002), while the second strand focuses on the combined dynamics of the real exchange rate and current account in response to different shocks (see inter alia; Alquist and Chinn, 2002; Singh, 2002; Chinn and Prasad, 2003; Giuliodori, 2004; Bussiere et al., 2005). Our study contributes to the second strand of literature and aims to provide a better understanding of the relationship between the exchange rates and current account in emerging countries.

In India, the liberalization of the financial markets coupled with the gradual opening of capital account has led to a significant surge in capital flows into the domestic economy. Such deregulation measures that drive greater economic efficiency and competency have intensified the impact of capital flows on the movements of exchange rates and current account balance. Considering the aforesaid market-oriented policy initiatives of the early 1990s, in 
our empirical analysis, we have incorporated the capital account variable in the estimated model in order to capture external shocks and potential structural breaks due to financial liberalization.

The rest of the paper is organized as follows. Section 2 presents the empirical framework and introduces the estimation equation used. Section 3 discusses the results. The final section presents the conclusion and some policy implications.

\section{METHODOLOGY AND DATA}

Following Kim et al. (2012), we develop a VAR model incorporating two endogenous variables, the real effective exchange rate (REER) and the ratio of current account to GDP (CAD), and one exogenous variable, the capital account to GDP ratio (KAD), to account for external shocks and potential structural breaks. Both nominal current account and capital account are first deflated using the wholesale price index (WPI) in order to convert them into real terms. The data are of yearly frequency for the period 1975-2011 and are sourced from the International Financial Statistics (IFS) CD-ROM (2012). ${ }^{1}$

We define a vector of endogenous variables in VAR and SVAR as follows:

$x_{t}=\left[R E E R_{t}, C A D_{t}\right]^{\prime}$

Consider the following infinite-order vector moving average (VMA) representation:

$\Delta x_{t}=C(L) \varepsilon_{t}$

where $\mathrm{L}$ is a lag operator, $\Delta$ is a difference operator, and $\varepsilon_{t}=\left[\varepsilon_{a, t}, \varepsilon_{b, t}\right]^{\prime}$ is a $(2 \times 1)$ vector for the covariance matrix of structural shocks $\Sigma$. The error term can be interpreted, respectively, as the real exchange rate shocks, and current account shocks. We assume that structural shocks have no contemporaneous correlation or autocorrelation. This implies that $\Sigma$ is a lower diagonal matrix.

model:

To implement the econometric methodology, it is necessary to estimate the following finite-order VAR

$[I-\Phi(L)] \Delta x_{t}=u_{t}$

where $\Phi(\mathrm{L})$ is a finite-order matrix polynomial in the lag operator and $u_{t}$ is a vector of disturbances. If the stationarity condition is satisfied, we can transfer Equation (3) to the VMA representation:

$\Delta x_{t}=A(L) u_{t}$,

where $\mathrm{A}(\mathrm{L})$ is a lag polynomial. Equations (2) and (4) imply a linear relationship between $\varepsilon_{t}$ and $u_{t}$ as follows:

$u_{t}=C_{0} \varepsilon_{t}$

In Equation (5), $C_{0}$ is a $2 \times 2$ matrix that defines the contemporaneous structural relationship among the variables.

\footnotetext{
${ }^{1}$ We have used the quarterly weighted average method to convert annual frequency data into quarterly frequency data in order to avoid the problem of low frequency of observations. Our findings, in general, are very similar to those that we report in the paper, and are available on request.
} 
Moreover, it is necessary to identify the vector of structural shocks so that it can be recovered from the estimated disturbance vector. We require four parameters to convert the residuals from the estimated VAR into the original shocks that drive the behavior of the endogenous variables. Since three of these four parameters are given by $\Sigma=C_{0} C_{0}$ ', one more identifying restriction needs to be added. According to Blanchard and Quah (1989), economic theory can be used to impose such restrictions. Thus, we impose an additional restriction on the long-run multipliers while freely determining the short-run dynamics. The long-run representation of Equation (3) is as follows:

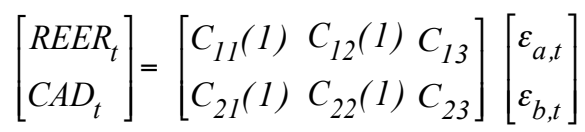

where $C(1)=C_{0}+C_{1}+C_{2}+\ldots 0$ are long-run multipliers in our SVAR model (long-run effect of $\Delta \mathrm{x}_{\mathrm{t}}$ ). We use a lower triangular matrix in our analysis. However, we add an additional variable, $K A R_{t}$, as an exogenous variable in both VAR and SVAR models. Next, we construct a SVAR and plot the impulse response functions (IRFs) of the variables in the system. Last, we study the forecast error variance decomposition of the SVAR model. The lag length incorporated in our VAR and SVAR models is determined based on the Akaike Information Criteria (AIC) since it is suitable for small samples (Liew, 2004).

\section{DISCUSSION OF EMPIRICAL RESULTS}

First, the time series property of each variable is checked using the Zivot-Andrews (1992) unit root test that allows for one unknown breakpoint in both the constant and trend that are endogenously determined from the data. All variables are found to be stationary at their level, although at different levels of statistical significance. The log of REER is stationary at 1 percent level of significance, while CAD and KAR are stationary at 5 percent and 10 percent levels, respectively. Thus, we estimate the VAR model at the level of each variable.

The standard VAR model is estimated using lag length 1 based on the AIC criterion. The estimated VAR model passed the various diagnostic tests. ${ }^{2}$ Moreover, none of the estimated characteristic roots of the model lie outside the unit root circle, thereby satisfying the stability conditions. In contrast to the conventional wisdom on exchange rate and current account balance, the IRF of one standard deviation positive shock to real exchange rate (appreciation) suggests a steady improvement in India's current account deficit; the effect seems to taper off in around $8-10$ years (see Figure 1).

Similar results regarding permanent shocks to the real exchange rate are obtained by Lee and Chinn (2006) and Chinn and Lee (2009) as well. A possible explanation for this anomaly may be the simultaneous rise in supply and demand for tradable goods after a productivity shock that lead to ambiguous changes in the current account position. In addition, the results seem plausible, particularly in the context of India, given the declining exchange rate pass-through (Patnaik and Shah, 2008; Samantaraya, 2009) due to administered oil and primary products prices, a credible monetary policy, and government incentives to maintain export competitiveness. ${ }^{3}$ Moreover, given the strong and permanent 'home-good preference' shock, the current account may also improve along with the rising real exchange rate (Chinn and Lee, 2009). Within a portfolio model framework, Blanchard et al. (2005) highlighted how a preference shock in favor of home exports induces a positive comovement in the current account and real exchange rate. Therefore, we contend that our results indicate, in the context of, inter alia, productivity innovations, technological innovations, and preference shocks, the dominance of permanent shocks on the movements of both the exchange rate and the current account of India.

\footnotetext{
${ }^{22}$ The model is free from serial autocorrelation, heteroscedasticity, and is normally distributed. All results, including that of the unit root analysis, are available on request.

${ }^{3}$ A declining exchange rate pass-through on account of reducing expenditure-switching effects would lead to an improvement in the current account.
} 
Figure 1. Impulse Response of standard VAR

Response to Generalized One S.D. Innovations \pm 2 S.E.

Response of RCAD to RCAD

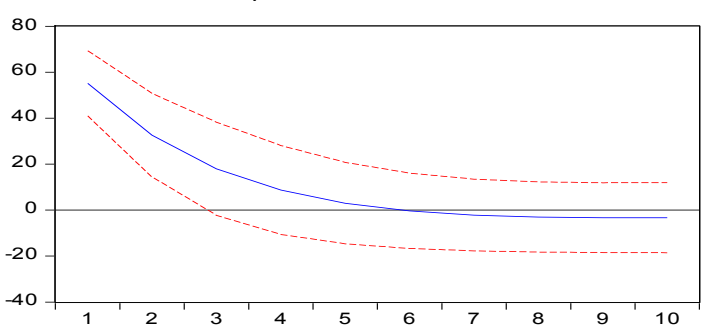

Response of LNREER to RCAD

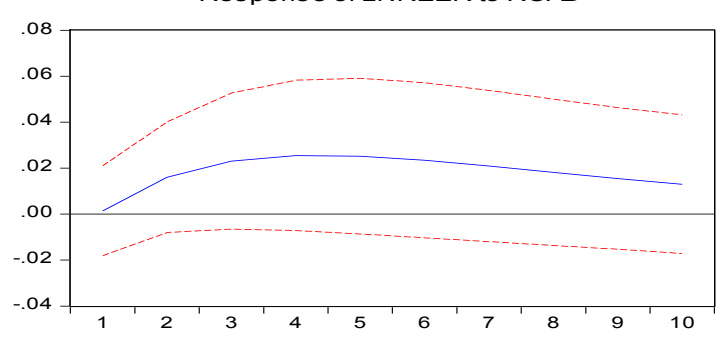

Response of RCAD to LNREER

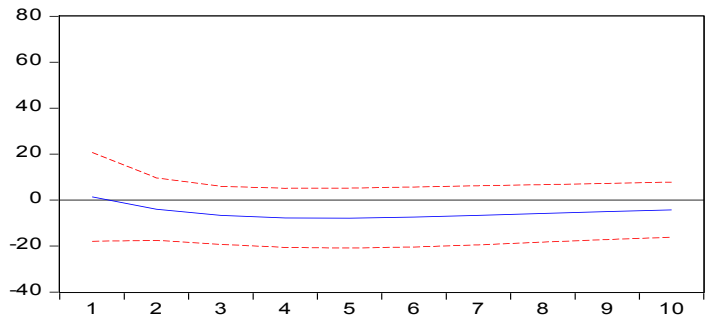

Response of LNREER to LNREER

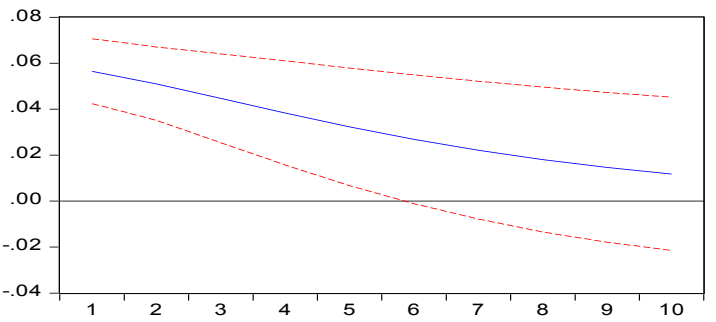

This anomaly is also observed in the impulse response of the real exchange rate to the current account shock. A positive current account deficit shock puts an upward pressure on the real effective exchange rate instead of a downward pressure. Given that exchange rates are influenced largely by the capital accounts flows rather than the current account position, this result seems logical. For example, a huge capital inflow, on one hand, would drive up the exchange rate and, on the other hand, make exports dearer relative to imports, thereby worsening the current account deficit. The trajectory of impulse response indicates that in response to one standard deviation shock to the current account, the real exchange rate appreciates, with maximum effect of 25 percent being realized in about 3-5 years period. However, the current account position changes by a maximum of 10 percent.

Further, we have used variance decomposition (VD) analysis to determine the changes in current account and exchange rate that are attributable to changes in the real exchange rate and capital account, respectively. As shown in Table 1, the results of the analysis reveal that currency appreciation/depreciation explains only around 0.5-3 percent of the up to four-year variance forecast and around 4-7 percent of the 5- to 10-year variance forecast for CAD. On the other hand, changes in CAD were found to explain around 4-17 percent of the 2- to 5-year variance forecast and around 19-24 percent of the 6- to 10-year variance forecast. The results, thus, indicate that most of the variations in current account and real exchange rate are explained by changes in these variables themselves instead of variations in the other variables in the system.

Table 1. Variance Decomposition

\begin{tabular}{ccccc}
\hline & \multicolumn{2}{c}{ Model: VAR } & \multicolumn{2}{c}{ Model: SVAR } \\
\hline Period & $\begin{array}{c}\text { Variation in CAD } \\
\text { explained by REER }\end{array}$ & $\begin{array}{c}\text { Variation in REER } \\
\text { explained by CAD }\end{array}$ & $\begin{array}{c}\text { Variation in CAD } \\
\text { explained by REER }\end{array}$ & $\begin{array}{c}\text { Variation in REER } \\
\text { explained by CAD }\end{array}$ \\
\hline $\mathbf{1}$ & 0.000 & 0.0634 & 30.786 & 28.485 \\
$\mathbf{2}$ & 0.553 & 4.2974 & 27.514 & 18.752 \\
$\mathbf{3}$ & 1.633 & 9.3089 & 25.591 & 13.606 \\
$\mathbf{4}$ & 2.949 & 13.638 & 24.890 & 10.940 \\
$\mathbf{5}$ & 4.232 & 17.011 & 25.022 & 9.566 \\
$\mathbf{6}$ & 5.324 & 19.519 & 25.575 & 8.862 \\
$\mathbf{7}$ & 6.175 & 21.335 & 26.250 & 8.507 \\
$\mathbf{8}$ & 6.800 & 22.624 & 26.885 & 8.334 \\
$\mathbf{9}$ & 7.242 & 23.526 & 27.412 & 8.254 \\
$\mathbf{1 0}$ & 7.544 & 24.147 & 27.817 & 8.221 \\
\hline
\end{tabular}


We further analyze the robustness of the results obtained from the standard VAR model within the framework of SVAR ${ }^{4}$. As shown in Figure 2, the IRF of one standard deviation shock to REER (appreciation) leads to a continuous fall in the current account deficit. Interestingly, the appreciating real exchange rate generates a current account surplus in around four years and the maximum effect is realized in around 6-7 years. On the other hand, the positive shock to the current account deficit causes the real exchange rate to appreciate sharply over a three-year period and taper off thereafter. The results of SVAR, thus, are largely in confirmation with those of the standard VAR model.

Figure 2. Impulse Response of SVAR

Response to Structural One S.D. Innovations

Response of RCAD to Shock1

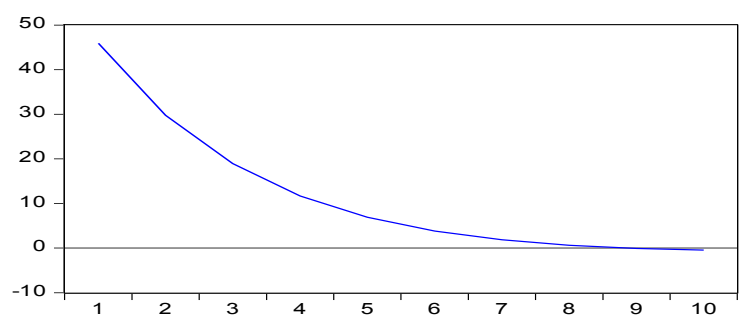

Response of LNREER to Shock 1

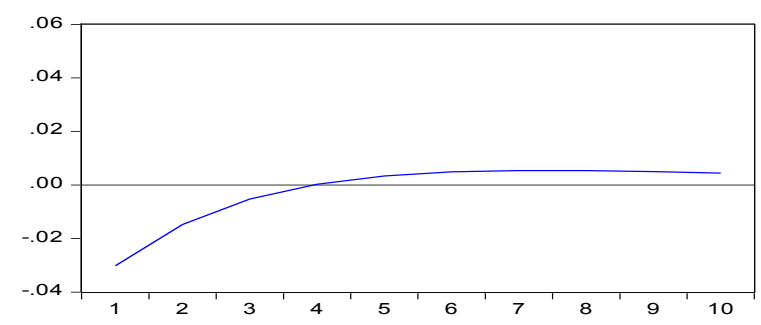

Response of RCAD to Shock2

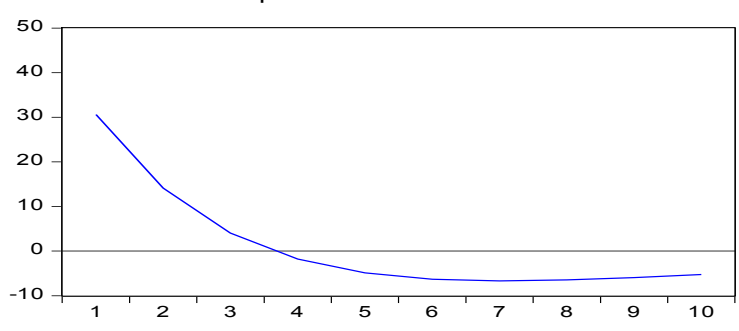

Response of LNREER to Shock2

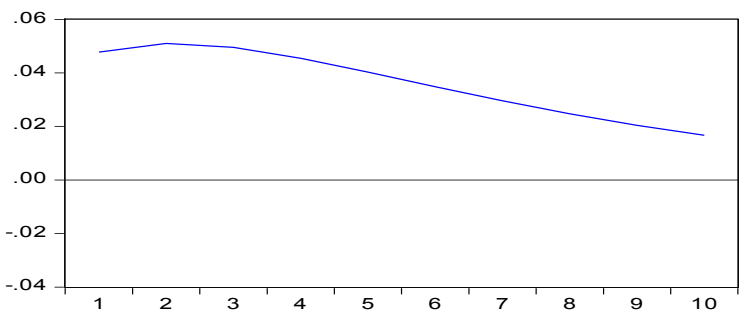

The VD of CAD reveals that changes in the real exchange rate explain around 31 percent of the up to oneyear variance forecast and around 25-27 percent of the 5- to 10-year variance forecast. Moreover, the variance decomposition of the real exchange rate suggests that around 28 percent of the up to one-year variance forecast is explained by the changes in CAD. Further, changes in CAD explain around 8 to 10 percent of the 2- to 4-year variance forecast and around 8 percent of the 5- to 10-year variance forecast for the real exchange rate. Thus, it is observed that both CAD and real exchange rate are largely influenced by the changes in these variables themselves rather than changes in the other variables in the system.

\section{CONCLUSION}

The study analyses the real current account and real exchange rate behaviors for India using VAR and SVAR. This method takes into account the potential endogeneity problem; it studies the dynamic interaction between current account and real exchange rate in a more holistic framework and captures feedback effects. The results of both the standard VAR and SVAR models suggest that a positive shock to the real exchange rate, that is, an appreciation in the exchange rate drives a steady improvement in the current account deficit of India. Our findings are somewhat consistent with those of Singh (2002), who studied the balance of trade model using a reduced-form specification, and showed that real exchange rate and domestic income significantly affect the balance of trade in India.

These findings can be explained in terms of the 'home-good preference' that refers to the simultaneous rise in demand and supply following an improvement in productivity and declining exchange rate pass-through. However, it was found that the increasing current account deficit exerts an upward pressure (appreciation) on the

${ }^{4}$ Shock 1 corresponds to the shock to CAD and Shock 2 corresponds to the shock to REER. 
real exchange rate, thus indicating stronger capital account flows. In terms of policy implications, this study suggests greater precaution and highlights that defensive initiatives are essential to prevent the rupee from plunging against major currencies, which will ease the widening current account deficit as well as maintain positive investor' sentiment, thereby facilitating smooth inflow of foreign capital. Our study can be extended to other countries for which higher frequency data are available or for a group of countries using panel regression methods.

\section{REFERENCES}

Alquist, R., and M. Chinn. 2002. Productivity and the euro-dollar exchange rate puzzle. NBER Working Paper, 8824.

Blanchard, O., and D. Quah. 1989. The dynamic effects of aggregate demand and supply disturbances. American Economic Review 79, no. 4: 655-73.

Blanchard, O., F. Giavazzi, and F. Sa. 2005. The U.S. Current Account and the Dollar. NBER Working Paper No. 11137.

Bussiere, M., M. Fratzcher, and G. Muller. 2005. Productivity shocks, budget deficits and the current account. European Central Bank Working Paper, 509.

Chinn, M., and E. Prasad. 2003. Medium term determinants of current accounts in industrial and developing countries: An empirical exploration. Journal of International Economics 59, no. 1: 47-76.

Chinn, M., and J. Lee. 2009. Three current account balances: A 'Semi-structuralist' interpretation. Japan and the World Economy 21: 202-12.

Devereux, M., and H. Genberg. 2007. Currency appreciation and current account adjustment. Journal of International Money and Finance 26: 570-86.

Giuliodori, M. 2004. Nominal shocks and the current account: A structural VAR analysis of 14 OECD countries. Review of World Economics 140, no. 4: 569-91.

Kim, S., and Y. Kim. 2012. "The RMB Debate: Empirical Analysis on the Effects of Exchange Rate Shocks in China and Japan," Working Papers 132012, Hong Kong Institute for Monetary Research.

Lee, J., and M. Chinn. 2006. Current account and real exchange rate dynamics in the G7 countries. Journal of International Money and Finance 25: 257-74.

Leonard, G., and A. Stockman. 2002. Current accounts and exchange rates: A new look at the evidence. Review of International Economics 10, no. 3: 483-96.

Liew, K. 2004. Which lag length selection criteria should we employ ? Economics Bulletin 3 (33), 1-9.

Patnaik, I. and A. Shah. 2008. Does the currency regime shape unhedged currency exposure. Working Paper 08/50, National Institute of Public Finance and Policy.

Samantaraya, A. 2009. An Empirical Analysis of Exchange Rate Pass-Through in India: Relevance for Inflation Management. Icfai University Journal of Monetary Economics, 7 (2): 17-31.

Singh, T. 2002 India's trade balance: the role of income and exchange rates. Journal of Policy Modeling, 24, 437452.

Zivot, E., and D. Andrews. 1992. Further Evidence on the Great Cash, the Oil-Price Shock and the Unit Root Hypothesis. Journal of Business and Economic Statistics 10 (3): 251-270. 